\title{
1. Introduction: examining international legal fictions
}

Probably no lawyer would deny that judges and writers on legal topics frequently make statements they know to be false. These statements are called 'fictions'. There is scarcely a field of the law in which one does not encounter one after another of these conceits of the legal imagination.

Lon L. Fuller, $1967^{1}$

\section{PREMISE OF THE BOOK}

The above quote from Fuller neatly captures the motivation behind this book. The basis for the book is that since legal fictions exist in all systems and types of law, international law is no different and this phenomenon deserves discrete detailed examination. For the question arises, what is the nature of international legal fictions? And, in turn, a host of other questions arise. What is a legal fiction? How do they exist in international law? What makes international legal fictions good or bad? Should international law use legal fictions? What does their existence in international law tell us about the international legal order itself?

These questions form the basis of the present enquiry. Whether this book satisfactorily addresses all of these questions is really up to you, the reader. Lon Fuller's book, Legal Fictions, is one of the most important works of scholarship on legal fictions. It remains the vade mecum to the subject. Campbell observed that however substantial Fuller's book is, it 'has to be treated as presenting not a full-blown theory, but a series of aperçus'. ${ }^{2}$

It is too grandiose a claim to suggest that this book is an equal of Fuller's. But like Fuller's work on the subject, this book seeks to provide novel insights into the nature of legal fictions. If one concludes that this book also presents a series of aperçus on the nature of international legal fictions, then the book will have succeeded.

For while the presence of legal fictions in municipal law has been identified and explored by scholars over centuries, the existence of legal fictions in

$1 \quad$ LL Fuller, Legal Fictions (Stanford University Press 1967) 1. Fuller's book includes three articles originally published in the Illinois Law Review (1930-1931).

2 K Campbell, 'Fuller on Legal Fictions' (1983) 2 Law and Philosophy 339, 340. 
international law, in contrast, has infrequently been studied. ${ }^{3}$ The sparsity of literature on international legal fictions does not preclude their examination. Nor does it preclude their evaluation. An approach is needed which, taking inspiration from the literature and perspectives of legal fictions found in municipal law, can outline the criteria of effectiveness of legal fictions in international law.

This book intends to pierce the veil and explore a subject not previously discretely examined in a monograph. The numerous examples of international legal fictions that this book discusses shows that this is not a dry subject of historic or academic value alone. Rather, just as fictions permeate through municipal legal systems, fictions permeate through the international legal order too. They affect international legal practice. Some of the examples drawn upon in the later Chapters of this book, show that fictions continue to be relied upon - even in the context of some of the most contentious international disputes of recent times.

Indeed, anyone with an interest in international law will have encountered some aspect of its fictions or artificiality. International law is not unique in occasionally having a tempestuous relationship with 'reality'. ${ }^{4}$ Like other legal orders, international law is no different when it applies fictions and makes use of abstract concepts.

Take 'states', for example, arguably the most important subject of international law, the artificiality of which will be familiar to international lawyers. Some states are denied the legal status of statehood, whereas some entities are recognised as states when they are not. ${ }^{5}$ We also pretend that some states remain in possession of territorial control over parts of its territory which has

3 Few exceptions include E Roucounas, A Landscape of Contemporary Theories of International Law (Brill 2019) Ch 25; JJA Salmon, 'The Device of Legal Fiction in Public International Law' (1974) 4(2) Georgia Journal of International \& Comparative Law 251; HS Maine, International Law: A Series of Lectures Delivered Before the University of Cambridge (Stanford University Press 1888); and A Vermeer-Künzli, 'As If: The Legal Fiction in Diplomatic Protection' (2007) 18 EJIL 37.

4 See Chapter 4 for greater detail on the concept of law not reflecting a mirror image of 'reality'. More said about this later. But see Fuller (n 1), esp. 104; J Bentham, 1983a: Deontology. Together with a Table of the Springs of Action and the Article on Utilitarianism (A Goldworth ed., OUP 1983); and H Vaihinger, The Philosophy of 'As If': A System of Theoretical, Practical and Religious Fictions of Mankind (CK Ogden tr., Martino Publishing 2009, originally published by K Paul, Trench, Trubner \& Co 1925).

5 This is examined in more detail in Chapter 3, Section III. 
been annexed by other states. ${ }^{6}$ We also deem the continuation of a state when in reality, it has ceased to exist. ${ }^{7}$

International law also makes use of the ability to 'deem' things to have occurred when they have not, and vice versa. For instance, some extradition treaties contain clauses that deem the relevant offence to have occurred in the territory of the requesting state, when it has not, so that the requesting state can request the extradition of the offender. ${ }^{8}$ Municipal law often makes use of the 'constructive' concept, such as constructive notice, knowledge, possession and trusts. International law also relies on this concept too. For instance, the doctrine of constructive presence permits a coastal state to deem the presence of a vessel within the territorial sea of the state, even though it was located on the high seas, because it participated in illegal act within its territory. ${ }^{9}$

Some of the classical tenets of public international law are fictions too. For example, while the notion that diplomatic missions constitute parts of the sending state's territory and the notion that ships are floating portions of the flag state's territory, no longer accurately reflect the present status of the law, they nonetheless served as important fictional building blocks from which the international legal order has built. The principle of the inviolability and immunity of diplomats, their effects and premises and the principle of the exclusive jurisdiction of the flag state over vessels flying its flag are settled and are attributable to those classic fictions. ${ }^{10}$

At the outset, the conceptual entanglement of the concepts of 'fictions', 'truth' and 'reality' should be disentangled. ${ }^{11}$ This book treats the concept of a legal fiction as a legal device, as a tool of legal craft. The term 'legal fiction', in this book at least, does not refer to a genre of literature. Neither does this book conflate the use of the term legal fiction with its more general use to criticise law or a particular provision or judgment, for instance. ${ }^{12}$ Rather, the book examines a specific tool of legal craft-legal fictions - and it seeks to shed light on their nature, effectiveness and implications for their application in international law.

\footnotetext{
6 See e.g., the non-recognition of the present status of region of Crimea, which is now factually under Russian territorial control, but is legally Ukrainian still.

7 See e.g., the consideration of the concept of the 'continuation of statehood' as discussed in Chapter 3, Section III, particularly the example of the recognition of states emerging from the collapse of the Soviet Union.

See Chapter 5, Section V, for consideration of this phenomenon.

See Chapter 5, Section II, for an examination of this fiction.

See Chapter 3, Section III, for further examination of this.

11 See Chapter 2, particularly Section III, for an examination of the concept of a legal fiction as a device of legal craft and its distinction from other tools.

12 These distinctions are examined in greater detail in Chapter 2.
} 
When it comes to the notions of 'truth' and 'reality', this book does not claim to produce a theory of the relationship between law and reality. Being focussed only on the concept of a legal fiction as a technical tool of legal craft ensures that such epistemological questions, however important, are beyond the scope of this book. In Chapter 2, it is made clear that the term 'reality' in this book should be understood to refer to the accepted facts of a given case or situation affected by the fiction. The terms 'truth' and 'reality' when used in this book should be understood in this limited sense: merely, to describe the facts engaged by the fiction.

\section{AIMS OF THE BOOK}

Brierly wrote in 1928 that,

Any intelligent study of the problems of international relations must raise the question of the role, if any, to be assigned in them to law. Unfortunately current discussions of the matter too often assume that this question can be answered by a priori methods, to the neglect of any serious examination either of the part that law is actually playing in the relations of states today, or of the conditions upon which an effective legal order in any society depends. ${ }^{13}$

This book intends to adhere to these principles. It does not adopt any dogmatic approach to the existence of legal fictions in international law. Nor is it an adherent of any school of jurisprudence or any particular approach to international law itself. Rather, this book takes international legal fictions as it finds them. It seeks to examine the phenomena through their specific manifestations, through examining how they work in practice and by interrogating individual examples of international legal fictions. The book bases its approach to international legal fictions upon their use and its central objective is to tell when their use is effective and when it is not. ${ }^{14}$

To do so this book has three principal aims. First, it aims to examine the nature of international legal fictions. It initially asks what is meant by the term 'legal fiction'. It is not the intention of this book to tread over well-trodden ground and examine the definitional and theoretical accounts of the nature of legal fictions alone. Rather, the book seeks to essentialise the constituent ingredients of legal fictions. The book then demonstrates how they are capable of being incorporated into the international legal system.

\footnotetext{
13 JL Brierly, The Law of Nations. An Introduction to the International Law of Peace (OUP 1928) v.

14 See Chapter 4 for an examination of how it is possible to determine the effectiveness of international legal fictions.
} 
Secondly, it aims to examine what makes international legal fictions effective and legitimate. The notion of a legal fiction may strike some, initially, to be contrary to the purposes of law but for reasons explored in greater detail in later Chapters of this book, this is naïve. It will be shown that there is a certain inevitability of the existence of legal fictions. This is true of all systems of law. Plus, it will be demonstrated that the use of fiction can actually assist the better application of the law. We should, therefore, concentrate our efforts on establishing when fictions are good and when they are bad and determining whether they assist or hinder the application of international law. This book investigates both the beneficial and detrimental aspects of international legal fictions. Consequently, it examines several examples of international legal fictions in order to flesh out and establish a test for their effectiveness and apply it to specific international legal fictions.

Thirdly, it aims to investigate the broader implications of the existence of international legal fictions for the international legal order. It reflects on the ramifications for international law, including its development and asks what the existence of international legal fictions can tell us of the nature of international law itself.

\section{OVERVIEW OF THE BOOK}

Chapter 2 examines the concept of a 'legal fiction'. It identifies the essential elements that all definitions of legal fictions include. It settles on a working definition of a legal fiction. It is explained that a legal fiction, as understood in this book, involves the conscious recharacterisation of the accepted operational facts such that alternative legal rules may apply to the recharacterised situation. The Chapter distinguishes legal fictions from lies and errors. It also distinguishes legal fictions from other legal devices such as legal presumptions, legal interpretation (including treaty interpretation) and the mere selection of facts.

The Chapter also scrutinises the various criticisms that have been levelled against legal fictions. For instance, the idea that legal fictions are tools of judicial deception is rebutted chiefly because of the consciousness involved-the 'real' facts are accepted and recognised, they are not hidden. It is also shown that fictions are not the exclusive work of the judiciary. They are created by legislatures and in international law, they are incorporated into treaties drafted and freely concluded by states.

Chapter 3 explores the presence of legal fictions in international law. It begins by identifying their sources. It is explained that these broadly reflect the recognised sources of international law. The Chapter also identifies a taxonomy of international legal fictions. It discusses the various attempts that have been made to categorise municipal legal fictions. Ultimately, the Chapter 
recognises that these attempts suffer from a lack of clarity and are not easily transposed to the international context.

The Chapter takes inspiration from Fuller's distinction between so called 'big' and 'little' legal fictions. ${ }^{15}$ It identifies two core categories of international legal fictions. First, it recognises the existence of constitutive international legal fictions. These fictions are those that underlie the international legal order, they constitute it. It is demonstrated that these fictions serve as some of the fundamental building blocks of the international legal system, serving as a basis upon which the more nuanced and complex legal order has subsequently built. It identifies the following fictions which fall into this category: the notion of international law as 'law'; the principle of sovereign equality; and aspects of international legal personality.

Having identified these, the Chapter identifies the second core category of international legal fictions - facilitative international legal fictions. These fictions are the primary focus of this book. It is explained in Chapter 3 that these fictions are more immediate in international legal practice in contrast to constitutive fictions. For they arise alongside and operate within the context of the application of international law. The Chapter explains that previous attempts to categorise similar fictions within the municipal context have been unfruitful. A more useful distinction to draw is that between effective and ineffective international legal fictions.

Chapter 4 explores the evaluation of international legal fictions. It seeks to establish a test from which it is possible to determine what makes international legal fictions good or bad. It scrutinises the work of Jeremy Bentham, Hans Vaihinger and Lon Fuller on this question and explains that despite their differences a point of convergence may be identified - the fidelity to law. The Chapter explores the concept of fidelity or coherence with law and suggests how international legal fictions can achieve this. In sum, this book claims that the effectiveness of international legal fictions depends upon the extent to which they are able to bring about outcomes which are consistent with the international laws they affect.

Chapters 5 and 6 apply the evaluative principles established in Chapter 4 to specific examples of international legal fictions. The Chapters forensically analyse the examples to flesh out the test for the determination of the effectiveness of international legal fictions.

Chapter 5 examines the elements of international legal fictions that make them effective. It explores several examples which demonstrate their effectiveness. It identifies the following themes which ensure this, including fictions which assist legal coherence, fictions which prevent illogical applications of

15 Fuller (n 1), ix-xi. This is examined in greater detail in Chapter 3. 
the law, shorthand fictions and those which assist the implementation of a particular legal regime - including treaty regimes.

In contrast, Chapter 6 examines the detrimental elements of international legal fictions. It is the counterpart of Chapter 5. For it too scrutinises specific examples of international legal fictions, but it does this to identify those aspects which make their use ineffective and problematic. It identifies the following themes which ensure this, including fictions which lack legal coherence, apply unconfined falsities, are impractical and those which are implemented to brazenly introduce legal change.

Chapter 7 reflects on the previous analysis. It identifies some important implications of the existence of international legal fictions. The Chapter reflects on the test adopted by this book for their evaluation. It explains that Chapters 5 and 6 support the conclusion that it is better to understand the effectiveness of international legal fictions according to their coherence with the international law/s they affect.

Chapter 7 also explores the concept of invalidity in international law. For one of the emerging themes out of the book is that fictions seem to arise when invalidity is found. Chapter 7 also reflects on the implications of international legal fictions for the nature of international legality. In particular, it seeks to demonstrate how fictions sit within a legal order that has both a general and specific contextual application. ${ }^{16}$ The Chapter addresses the question whether the existence of international legal fictions shows the continued primitiveness of international law. ${ }^{17}$ The Chapter explains why this is not the case. In fact, the presence of fictions is both inevitable and, consistent with the evaluative approach developed in the book, potentially beneficial.

The book concludes by reflecting on the series of observations (possibly aperçus) made within it. It ends with an appeal that while the subject of legal fictions can rely on a rich history of examination in municipal law, this is not true of international law. This book, at the very least, seeks to establish some interest in this subject in the international context.

16 In this context, general refers to 'general' international law and 'specific' refers to the sub-disciplines of international law.

17 As suggested in Y Dinstein, 'International Law as a Primitive Legal System' (1986-1987) 19 NYU J Int'l L. \& Pol. 1. 